

\section{$9^{\text {th }}$ International Conference on}

Agriculture and Rural Development

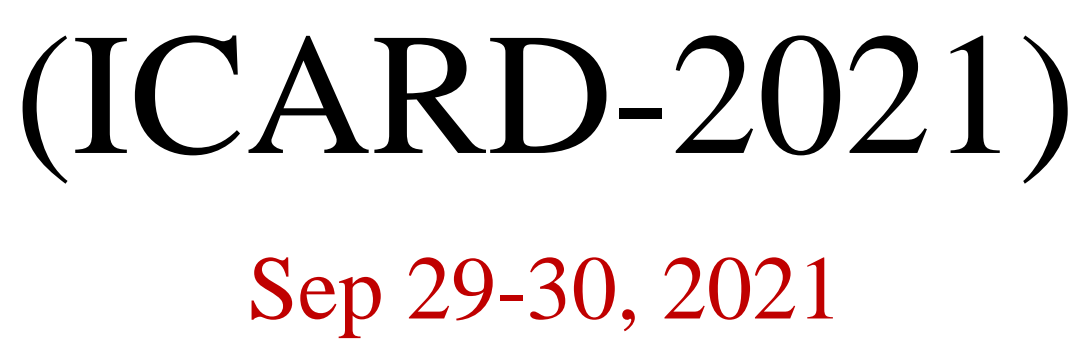

Copyright @ 2021 International Research and Development Center for Publication

DOI: $\underline{10.22161 / \text { conf.icard.sep.2021 }}$

\section{Publisher}

$$
\text { IRDCP }
$$

Email: irdcp.publication@gmail.com | conference.irdcp@gmail.com Web: https://irdcp.org/ 


\section{$\underline{\text { About IRDCP }}$}

International Research and Development Center for Publication (IRDCP) is a nonprofit organization for promoting research and development around the world. IRDCP is the bridge between the quality publisher and researchers. It provides the platform to researchers and academicians for publication in the Scopus Indexed Journals, SCI Journals, Web of Science Journals, UGC Approved Journals, NAAS Rated Journals, Google Scholar Indexed Journals and other good quality DOI journals.

IRDCP is also a partner organization for publication in conference proceedings. We organize the International conferences for publication in SCOPUS indexed and other refereed journals as per the requirement of the authors of the manuscripts. The manuscripts submitted to IRDCP should be plagiarism free and well coherent in all sense.

The scope of publication with the IRDCP covers all type of review and research manuscripts including the Exploratory \& Explanatory Research, Descriptive \& Theoretical Research, Applied Research \& Action Research, Cross-Sectional Research, Quantitative \& Qualitative Research in the field of engineering \& technology, agriculture \& environmental, Social science \& Humanities, Literature \& Education development, Medical \& Health Science.

\section{The vision of IRDCP :}

IRDCP endeavors to promote global excellence in the field of research \& development through diligent applications of advanced technology for the holistic development of society. Also, IRDCP is committed to motivate and persuade the researchers to take up the projects for the continuous development of human society and make this world a better place to live in. The IRDCP has a steadfast commitment be the fulcrum of the ocean of knowledge around which efforts of researchers move about. 


\section{$\underline{\text { About Conference }}$ \\ International Conference on Agriculture and Rural \\ Development (ICARD-2021)}

During the worldwide lockdown due to COVID 19 pandemic, a lot of important activities have come to a halt. However, when we look at the brighter side, all of us have more time for adding to our knowledge and insights.

With this aim, to keep contributing to learning and motivation International research and development Center for publication is going to organize a two-day International Conference with the title "International Conference on Agriculture and Rural Development (ICARD-2021)" on Sep 29-30, 2021 through online mode.

We hope, this online mode of the conference in COVID-19 pandemic will be an appreciable step in promoting the research activities and new information between researchers, developers, students, academicians and practitioners working in and around the world by keeping the social distance in view to stop the spread of COVID-19 disease. This conference aims is to present the current researches being carried out in the field of social science and education development around the globe.

Prospective authors from academia as well as industry are invited to submit their abstracts that illustrate original/unpublished works and industrial applications describing advances and significant innovations in the field. 


\section{International Advisory Committee}

Aicha El Alaoui, Sulatn Moulay Slimane University, Morocco

Akas Pinaringan Sujalu, University of 17 Agustus 1945 Samarinda, Indonesia

Dr. Hamid Saremi, President(Chancellor), Assrar Higher Institute of Education, Mashad, Iran

Assoc. Prof Dr. Mehmet Karakaş, General biology and zoology, Physiology, Ankara University,

TurkeyProf. (Dr.) Sandro Serpa, Department of Sociology, University of the Azores, Portugal

Chew Fong Peng, University of Malaya, Malaysia

Demetria Gerold Mkulu, St. Augustine University of Tanzania

Dr. A. Heidari, Faculty of Chemistry, California South University (CSU), Irvine, California, USA

Dr. Abd El-Aleem Saad Soliman Desoky, Faculty of Agriculture, Sohag University, Egypt

Dr. Alexandra D. Solomou, Agricultural Engineer, Hellenic Agricultural Organization "DEMETER", Institute of Mediterranean and Forest Ecosystems, Terma Alkmanos, Ilisia, 11528, Athens, Greece.

Dr. Anil Matthew, Research Supervisor, Former Head of Department of English, Hislop College Nagpur, India

Dr. Ekrem BÖLÜKBAŞI, Molecular biology and Biotechnology, Amasya University, Turkey

Dr. Elechi Felix Aja, Ebonyi State University, Abakaliki, Nigeria

Dr. Etim Nse Akpan, Federal University Wukari, Nigeria

Dr. Jyoti Patil, Principal, Renuka Mahavidyalaya, Besa Nagpur, India

Dr. K. Srujan Raju, CMR Technical Campus (CMRG), CSI State Student Coordinator, Telangana State, India

Dr. M. Kannan, SCSVMV, Kanchipuram, India

Dr. Mahona Joseph Paschal, Service-Learning ambassador in Tanzania.

Dr. Md Mahadhi Hasan, Assistant Professor, Department of English, Southeast University, Bangladesh.

Dr. Mehmet Firat Baran, Associate Prof. , Faculty of Technology, Department of Energy Systems

Engineering, Altinsehir, Adiyaman, Turkey

Dr. Mohammed Y. Suliman, Northern Technical University, Iraq

Dr. Neel Kamal Purohit, S.S. Jain Subodh P.G. College, Rambagh, Jaipur, India

Dr. Onyemauche Uchenna Chinyere, Federal University of Technology Owerri Imo State Nigeria

Dr. P. D. Nimsarkar, RTM Nagpur University Nagpur, India

Dr. Parul Mishra, GD GOENKA University, India

Dr. Payal Chadha, University of Maryland University College Europe, Kuwait

Dr. Raghvendra Singh, Pranveer Singh Institute of Technology, India

Dr. Sandhya Lanjewar, Central Institute of English Hyderabad, India

Dr. Sunil Kumar Mishra, Amity School of Liberal Art, India

José G. Vargas-Hernández, Núcleo Universitario Los Belenes CUCEA, Zapopan, Jalisco C.P. 45100;

México

Kofand Anwar, American Stratford University, Virginia

Mohammed Y. Suliman, Northern Technical University, Iraq

Mohd Muntjir, College of Computers and Information Technology, Taif University, Kingdom of Saudi Arabia

Monica Aparecida da Rocha Silva, Universidade de São Paulo, Brazil

Mr. Sagar Jamle, Oriental University Indore, India

Muvunyi Ronaldo, Taiyuan University of Technology, China

Nyangono Biyegue Christine Fernande Epse Ayou Bene, University of Douala/ enset, Cameroon

Prof Dr. Noman Omar Sattar, National Defense University, Islamabad, Pakistan 
Prof. Dr. Eng. Ahmed Kadhim Hussein, College of Engineering, Department of Mechanical Engineering, Babylon University, Babylon City, HIILA, IRAQ

Prof. Dr. Flávio de São Pedro Filho, Coordinator of the GEITEC / UNIR / CNPq, Brazil. Federal University of Rondônia, Brazil

Prof. Liu Wenxiang, Hubei University, Wuhan, China

Professor Tamuno-Omi Godwin Dappa, Federal University Wukari, Nigeria

Sahar Mirzaei, Horticultural Science Research Institute, Agricultural Research, Education and Extension Organization (AREEO), Mahallat, Iran.

Samuel dos Santos Junio, Instituto Federal de Educação, Ciência e Tecnologia de Rondônia

- Campus Porto Velho Zona Norte, Brazil

Sandro Serpa, University of the Azores, Portugal

Titus O. Pacho, Kisii university , Kenya 


\section{Message}

I am extremely pleased to share that International Research and Development Center for Publication (IRDCP) is organizing a two days International Conference on Agriculture and Rural Development (ICARD-2021) on Sep 29-30, 2021.

I am sure the state of art lectures from the invited experts and the research findings of researchers, academicians, utility engineers will enrich the knowledge of all the participants. It will provide an excellent opportunity for students to learn new ideas.

I offer my best wishes to the whole team of the organizing committee, the participants, and volunteers for the grand success of the conference.

Dr. Kiran

Convenor ICARD-2021 


\section{Message}

I am happy to know that International Research and Development Center for Publication (IRDCP) is organizing a two days International Conference on Agriculture and Rural Development (ICARD-2021) on Sep 29-30, 2021. I am sure that, this conference would provide an ideal platform for the academicians, scholars and experts to present and exchange their research findings and Ideas.

I wish the conference a great success.

Prof. (Dr.) Hamid Saremi President (Chancellor) Assrar Higher Institute of Eduction (Deemed to be University ) Mashad - Iran (Ex- Vice- Chancellor Islamic Azad University, Quchan Branch - Iran ) 
Effect of Intervention on Self-Confidence Levels among Rural Adolescent Girls during Covid-19 in Telangana State

Sana Bari ${ }^{1}$, G. Swarupa Rani², M. Sarada Devi ${ }^{3}$, R. Geetha Reddy ${ }^{4}$

E- Agriculture leads to rural development in India: A Review

Nidhi Thakur

Inportance of phyto-chemicals for control of mite (Polyphagotarsonemus latus Banks)

Sunil Kumar Ghosh

$\underline{6}$

Infestation of whitefly (Bemisia tabaci G.) on tomato crop (Solanum lycopersicum $\mathrm{L}$.) and its management

Thakoor Pavan 

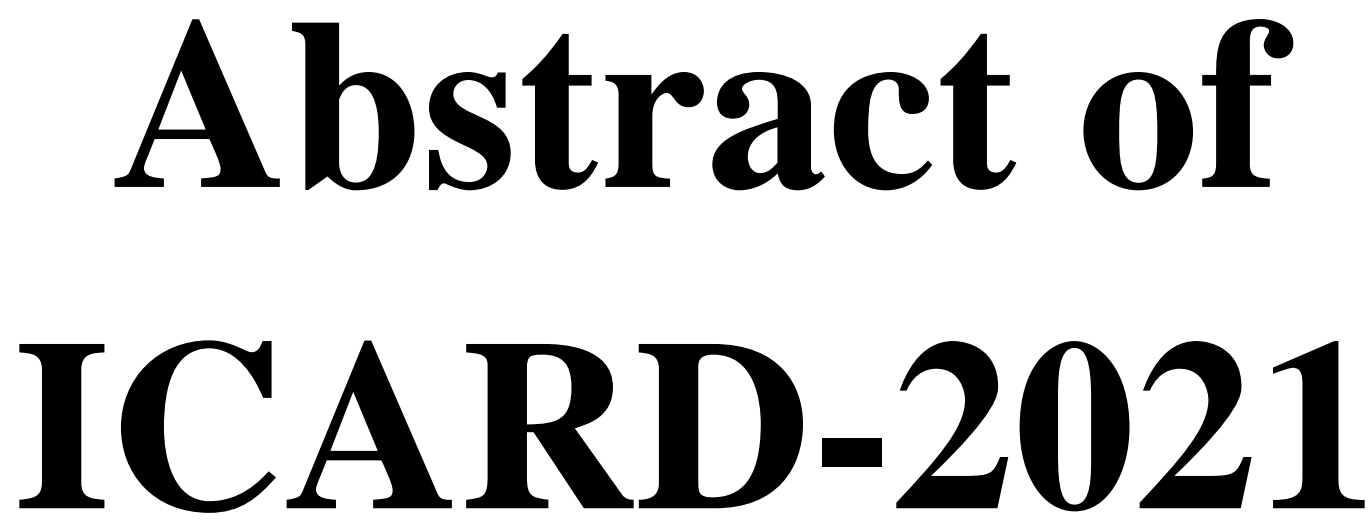


\title{
Effect of Intervention on Self-Confidence Levels among Rural Adolescent Girls during Covid-19 in Telangana State
}

\author{
Sana Bari ${ }^{1}$, G. Swarupa Rani ${ }^{2}$, M. Sarada Devi ${ }^{3}$, R. Geetha Reddy ${ }^{4}$ \\ ${ }^{1}$ M.Sc. Scholar, Department of Human Development and Family Studies, Professor \\ Jayashankar Telangana State Agricultural University, Hyderabad,Telangana, India. \\ ${ }^{2}$ Assistant Professor, Department of Human Development and Family Studies, Professor \\ Jayashankar Telangana State Agricultural University, Hyderabad, Telangana, India. \\ ${ }^{3}$ Professor and University Head(Rtd.), Department of Human Development and Family \\ Studies, Professor Jayashankar Telangana State Agricultural University, Hyderabad, \\ Telangana, India. \\ ${ }^{4}$ Professor and University Head(EECM \& HDFS), Department of Extension Education and \\ Communication Management, Professor Jayashankar Telangana State Agricultural \\ University,Hyderabad,Telangana, India.
}

\begin{abstract}
The COVID-19 pandemic and the associated measures has left many people with low self-confidence particularly the adolescents where they've been left alone as they have lost touch with their routine, friends and family, accompanied with uncertainty of exams and online classes affecting their wellbeing. Thus, the aim of this investigation was to evaluate levels of self-confidence and to know the effect of intervention on self-confidence levels among the rural adolescent girls during the COVID-19 pandemic. A sample of 60 rural adolescent girls were selected for the study. An experimental design was used with a self-confidence scale which was developed to measure the self-confidence levels of the rural adolescent girls during pre-test and post-test. The results of the study depicted that, the self-confidence levels of the majority of the rural adolescent girls were in average and low category during the pre-test has significantly improved to high category during the post-test. Further the findings also found the paired t-test value was $9.79 * *$ which indicates a high significant difference at 0.01 level of probability. Therefore, it was concluded from the results of the study that the intervention on self-confidence levels was effective during the COVID-19 pandemic.
\end{abstract}

Keywords - COVID-19, Rural adolescents, Self-confidence, Intervention 


\section{References:}

[1] Akbari, O and Sahibzada. 2020. Students' Self-Confidence and Its Impacts on Their Learning Process. American International Journal of Science and Research.5(1).

[2] Blegur, J., Wasak, M.R.P and Rosari, R. 2019. Student's Self-Confidence Restoration with Peer Mentoring Strategy. European Scientific Journal. 15(19): 129.

[3] Coudevylle, G., Gernigon, C and Ginis, K.M. 2011. Self-esteem, self-confidence, anxiety and claimed self-handicapping: A mediational analysis. Psychology of Sport and Exercise. 12. 670-675.

[4] Hatzigeorgiadis, A., Zourbanos, C.F.Z., Sofia, M and Theodorakis, Y. 2009. Mechanisms underlying the self-talk-performance relationship: The effects of motivational self-talk on self-confidence and anxiety. Psychology of Sport and Exercise. 10(1): 186-192.

[5] Li, DJ., Ko, N.Y., Chen, Y.L., Wang, P.W, Chang Y.P and Yen, C.F. 2020. Confidence in coping with COVID-19 and its related factors among the public in Taiwan. Psychiatry and Clinical Neuroscience. 74(11): 608-610.

[6] Verma, M.K., Kumar, P and Yashmeen. 2019. Effect of Psychological Interventions for Improving Self-Confidence of University Students. International Journal of Recent Technology and Engineering.7(6).

[7] Parveen, N. 2017. Emotional Maturity and Self Confidence among Adolescent Students. International Journal of Indian Psychology. 5(1): 2348-5396.

[8] Sindhuja, S and Vanitha, J. 2019. A study on the Mental Health and Self Confidence of B.Ed Students in Coimbatore District. International Journal of Trend in Scientific Research and Development. 3(4): 1290-1292. 


\title{
E- Agriculture leads to rural development in India: A Review
}

\author{
Nidhi Thakur
}

Assistant Professor, Swami Swatantranand Memorial College, Dinanagar, India

\begin{abstract}
The United Nations' Food and Agriculture Organization (FAO) has developed an eagriculture plan in partnership with the International Telecommunication Union to assist countries in using information and communication technologies to support rural development. Information and communication technologies (ICTs), which are mostly focused on agriculture, can assist enhance agricultural growth by enhancing farmers' access to essential information, allowing them to make the best decisions and manage their resources responsibly. In this era of climate change, when extreme weather occurrences are the norm, e-agriculture can provide services such as weather forecasts and disaster alerts that can assist farmers in making informed decisions. Agriculture has evolved into a knowledge-intensive industry, and having access to the appropriate information at the right time can make all the difference in a small-holder farmer's livelihood. Governments can supply rural communities with weather, market pricing, and insurance information that adds to their livelihoods with the correct kind of ICT services. Many of the challenges in the agricultural sector can be solved by having access to the correct information. Disaster planning and management, including measures like wise water management, watershed upkeep, and reliable meteorological information, can go a long way toward mitigating the effects of weather and climate change. Developed countries are already implementing a variety of agricultural technologies. Small-holder farmers in underdeveloped nations benefit from e-agriculture because it makes technology more accessible and affordable. Simple technology, such as soil health analysis, can assist a farmer in determining the sort of fertilizer to use in his land. Another excellent idea is to connect farmers with markets by providing market information and assisting them in receiving electronic payments. Initiatives like E-Choupal have proved the power of bringing communities together in India, A strategic approach to integrating the growth and reach of ICTs in other industries such as banking, insurance, and mobile technologies for agriculture is essential for identifying crucial services and solutions and ensuring their long-term viability. This research investigates the possible contribution of e-agriculture to the development of rural areas and the improvement of farmers' livelihoods.
\end{abstract}

Keywords - E- Agriculture, information Technology, Rural Development. 


\section{References:}

[1] Agarwal, B. "Social Security and the Family: coping with Seasonality and Calamity in Rural India" in E. Ahmad et al (eds), Social Security in Developing Countries, Oxford: Oxford University Press, 1991

[2] Gender, Environment and Poverty Interlinks in Rural india: Regional Variations and Temporal Shifts, 1971-1991. UNRISD Discussion Paper 62, Geneva, 1995.

[3] 'Environmental Action, Gender Equity and Women's Participation', Development and Change, 28 (1997): 1-44.

[4] Beck, T. "Common Property Resource Access by the Poor and Class Conflict in West Bengal”, Economic and Politicial Weekly, 29:4(1994): 187-196.

[5] Beck, Tony. Madan G Ghosh. "Common Property Resources and the Poor: Findings from West Bengal”, Economic and Political Weekly. 35:3 (January, 2000): 147-153. 


\title{
Inportance of phyto-chemicals for control of mite (Polyphagotarsonemus latus Banks)
}

\author{
Sunil Kumar Ghosh
}

\begin{abstract}
Department of Agricultural Entomology, BCKV, Kalyani, West Bengal-741235, India.
\end{abstract}

\begin{abstract}
Chilli (Capsicum annum L.) is an important spice and vegetable crop, commercially grown in India throughout the year. Chilli plant is susceptible to various insect and mite pests of which yellow mite, Polyphagotarsonemus latus (Banks), (Tersonemidae: Acarina) is most predominant. The mites attack young apical leaves, flower buds and cause curling and crumpling of young developing plant parts resulting shedding of flower buds, flowers and developing fruits. The incidence of this mite population always remained higher on upper canopy of the plant followed by middle canopy and lower canopy. Mites were most densely populated in the young and new leaves of chilli plant on upper canopy. So sprays should be carefully taken on the upper canopy. Among the seven treatments evaluated microbial toxin- avermectin resulted in the best suppression of mite population ( $86.32 \%$ suppression), closely followed by chemical insecticide, fenazaquin $(73.07 \%$ ) and mixed formulation of botanical pesticide, azadirachtin with botanical extract, Spilenthes (70.99\%). The botanicals, Spilanthes paniculata floral parts and garlic were extracted in methanol. Four sprays at 10 day intervals were made. Mite population was recorded 3, 6 and 9 days after each spraying. Avermectin and mixture of azadirachtin with botanical extracts gave moderate to higher mite suppression (more than $64 \%$ suppression). Considering moderate to higher efficacy as well as its low toxicity to natural enemies and minimum impact on human health microbial toxin, botanical insecticides, botanical extracts can be incorporated in future Integrated Pest Management (IPM) and organic farming. Azadirachtin individually did not produce higher results but when mixed with botanical extracts gave higher results of mite control recording more than $64 \%$ suppression. This treatment also is recommended for general farmers use.
\end{abstract}

Keywords - Bio-pesticides, Microbial toxin, Plant extract, Organic cultivation, IPM.

\section{References:}

[1] Bala, S.C., Karmakar, K., and Ghosh, S.K. (2015). Population dynamics of mite , Aceria tulipae Keif. on garlic (Allium sativum L.) and its management under Bengal basin. International Journal of Science, Environment and Technology, 4(5), 1365-1372.

[2] Bala, S.C., and Ghosh, S.K. (2016). Host plant resistance-cum-chemical control approach for the sustainable management of yellow mite, Polyphagotarsonemus latus (Bank) Journal of Entomological Research, 40 (4), 373-377. 
[3] Chakraborty, K., and Ghosh, S.K. (2010). Incidence of Coccinella septempunctata in brinjal with some pesticides. Current advances in Agricultural Sciences, 2(2), 129-130.

[4] Ghosh, S. K. (2013 a). Incidence of red spider mite (Tetranychus urticae) on okra (Abelmoschus esculentus (L.) and their sustainable management. Current Biotica, 7(1\&2), 40-50.

[5] Ghosh, S.K. (2013b). Sustainable management of red spider mite (Tetranychus sp.) infesting eggplant (Solanum melongena) at field level. Uttar Pradesh J. Zool., 33(2), 175180.

[6] Ghosh, S.K. (2019). Climate impact on red spider mite (Tetranychus sp. Koch) infesting eggplant (Solanum melongena L.) and their management using plant extracts. Journal of Entomological Research, 43 (3), 345-350.

[7] Ghosh, S.K., and Chakraborty, G. (2012). Integrated field management of Henosepilachna vigintioctopunctata (Fabr.) on potato using botanical and microbial pesticides. Journal of biopesticides. 5 (Supplementary),151-154.

[8] Ghosh, S.K., and Chakraborty, K. (2014). Bio-Efficacy of plant extracts against red spider mite (Tetranychus spp. ) infesting brinjal (Solanum melongena L.). Research journal of Agricultural and Environmental Sciences. 1, 26-31.

[9] Ghosh, S.K, Laskar, N., and Senapati, S.K. (2007). Seasonal incidence of predator Menochilus sexmaculatus Berliner on brinjal and harmful effect of insecticides on the predator. Indian Journal of Agriculture Research, 41(2), 102-106.

[10] Ghosh, S.K., Mahapatra, G. S. S., and Chakraborty, G. (2009). Field efficacy of plant extracts and microbial insecticides against aphid (Aphis gossypii) infesting okra (Abelmoschus esculentus). Redia, Itali XC11, 249-252.

[11] Ghosh, S.K., Mandol, T., and Chakraborty, K. (2016). Population fluctuation of aphid (Aphis craccivora Koch..) infesting Som plant leaves (Machilus bombycina King..) and its management. Journal of Entomological Research, 40 (3), 235-241.

[12] Ghosh, S.K., Mandal, T., Biswas, S., and Chakraborty, K. (2012). Field evaluation of cultivars and bio-efficacy of insecticides against pest complex of ladysfinger (Abelmoschus esculentus ). Journal of applied Zoological research, 23(2), 121-128.

[13] Ghosh, S.K., Sonowal, M., Chakraborty, G., and Pal, P.K. (2009) Bio-efficacy of microbial formulation against red spider mite (Tetranychus urticae Koch.) infesting ladysfinger (Abelmoschus esculentus L.) Green Farming, 2(10),685-688.

[14] Ghosh, S.K., Chakraborty, K., and Mandal, T. (2013). Bio-Ecology of Predatory Coccinellid Beetle, Coccinella septempunctata (Coleoptera: Coccinellidae) and its Dynamics in Rice Field of Terai Region of West Bengal, India. Internal Journal of Bioresource and Stress Management 4 (4), 571-575.

[15] Karmakar, K. and Bala, S.C., and Ghosh, S.K. (2017). Population dynamics of sheath mite (Stenotarsonemus spinki) Infesting rice cultivar IET-4786 and its management under West Bengal. Journal of Entomology and Zoology Studies, 5(4), 663-666. 
[16] Mandol,T., Ghosh, S. K., and Chakraborty, K. (2016). Seasonal incidence of thrips infesting Som plant leaves (Machilus bombycina King.) and their management, International Journal of Science, Environment and Technology, 5 (4), 2245-2256.

[17] Mandol, T., and Ghosh, S.K. (2020). Climate impact on spider mite (Tetranychus sp. koch) on som plant leaves (Machilus bombycina king) and control using phyto-chemicals. Journal of Entomology and Zoology studies.(JEZS), 8(5), 559-564.

[18] Priyadarshini, S., Ghosh, S.K., and Nayak, A.K. (2019). Field screening of different chilli cultivars against important sucking pests of chilli in West Bengal. Bulletin of Environment, Pharmacology and Life Sciences (JEZS), 8(7), 134-140.

[19] Priyadarshini, S. Pal, S., and Ghosh, S.K. (2017). Field screening of chilli cultivars against thrips (Scirtothrips dorsalis Hood.) and its management under West Bengal condition. Journal of Entomology and Zoology Studie,. 5(6), 2106--2110.

[20] Subba, B., Pal, S., Mandal, T., and Ghosh, S.K. (2017). Population dynamics of white fly (Bemisia tabaci Genn.) Infesting tomato (Lycopersicon esculentum L.) and their sustainable management using bio-pesticides. Journal of Entomology and Zoology studies, 5(3),879883.

[21] Thakoor, P., Ghosh, S.K., and Bala, S.C. (2020). Effect of abiotic factors on seasonal incidence and bio-efficacy of some newer insecticides against white fly on tomato crop in West Bengal. Journal of Entomology and Zoology studies, 8(3), 267-271. 


\title{
Infestation of whitefly (Bemisia tabaci G.) on tomato crop (Solanum lycopersicum L.) and its management
}

\author{
Thakoor Pavan
}

\begin{abstract}
Research Scholar, Department of Agricultural Entomology, BCKV, Kalyani, West Bengal741235 , India.
\end{abstract}

\begin{abstract}
Tomato (Solanum lycopersicum L.) crop is susceptible to various insect pests of which whitefly (Bemisia tabaci Genn.) is the most predominant. Whitefly population first appeared in the field during 48th standard metrological week (SMW) that is 0.15 per three leaves. After that the population progressively increased and reached its peak (4.5whitefly per 3 leaves) in the 7th meteorological week when average temperature, relative humidity and bright sunshine were 21.9 0C, $66.83 \%$ and $5.6 \mathrm{hrs}$ respectively. Correlation studies between whitefly population and weather parameters revealed that whitefly population showed significant positive correlation with temperature maximum while significant negative correlation with relative humidity(maximum, minimum and average). Maximum population reduction was found in the insecticidal treatment Imidacloprid 30.5 SC @ $0.004 \%$ active ingredient concentration $(90.62 \%)$ and Diafenthiuron 50 WP @ $0.05 \%$ active ingredient concentration (89.29\%).These were followed by Dimethoate 30 EC @ 0.06\%, Dinotefuran 20 SG @ 0.006\%, Spinosad 45 SC @ 0.007\%, Clothianidin 50 WDG @ 0.005\% and Flonicamid 50 WG @ 0.015\% active ingredient concentrations, which recorded $(85.21,78.03,76.48,71.00$ and $68.46 \%$ reduction over control). In untreated control the maximum number of whiteflies recorded was 4.00 per 3 leaves.
\end{abstract}

Keywords:- Tomato, whitefly, population dynamics, bio-efficacy.

\section{References:}

[1] Chakraborty, K., and Ghosh, S.K. (2010). Incidence of Coccinella septempunctata in brinjal with some pesticides. Current advances in Agricultural Sciences, 2(2), 129-130.

[2] Das, K., Biswas, S., Chakraborty, G., and Ghosh, S.K.(2010). Efficacy of insecticides against Jassid (Amrasca biguttula biguttuka Ishida) on okra in terai agro-ecology of West Bengal. Journal of Applied Zoological Research, 21 (1), 33-35.

[3] Ghosh, S.K. (1999). Studies on the pest constraints of brinjal and their management under terai region of West Bengal. Doctoral thesis, BCKV, Mohanpur, India.

[4] Ghosh, S.K. (2012). Integrated field management of white fly (Bemisia tabaci genn.) infesting ladysfinger (Abelmoschus esculentus L.) using biopesticides. Proceedings of conference on Agriculture, Science and Engineering (ICASE2012), 1(1), 118-121. ISBN: 
978-84-612-8486-3, Publiser: Rivers State University of Science and Technology, Port Harcourt, Nigeria.

[5] Ghosh, S.K. (2013). Incidence of Tetranychus urticae on Abelmoschus esculentus and their sustainable management. Current Biotica, 7, 40-50.

[6] Ghosh, S.K. (2013). Harmful effect of insecticides in the population dynamics of spiders on lady's fingers Abelmoschus esculentus (L.) at field level. American-Eurasian Journal of Agricultural \& Environmental Sciences, 13 (9), 1181-1186 ref.35.

[7] Ghosh, S.K. (2014). Incidence of Bemisia tabaci and their sustainable. Publisers: Johann Heinrich von Thünen-Institut RAHMANN G \& AKSOY U (Eds.) Building Organic Bridges, 2:623-626.

[8] Ghosh, S.K. (2016). Harmful effect of insecticides against predator, Coccinella sp. (Lady bird beetle) on eggplant (Solanum melongena L.). Uttar Pradesh Journal of Zoology, 36(1), 17-23.

[9] Ghosh, S.K. (2017). Seasonal Incidence of aphid (Aphis gossypii Glove.) Infesting tomato (Lycopersicon esculentum L.) and their management by using botanical pesticides. International Journal of Advances in Science Engineering and Technology, 5(3, Spl. Issue1),14-17.

[10] Ghosh, S.K. (2020). Environmentally sound approach for management of tomato whitefly (Bemisia tabaci Genn.). Journal of Entomology and Zoology studies.(JEZS), 8(6), 814-818.

[11] Ghosh, S.K. and Senapati, S, K. (2002). Field evaluation of pesticides from different origin against pest complex of brinjal under terai region of W. B. Crop Res, 23(1), 108-115.

[12] Ghosh, S.K, Laskar, N., and Senapati, S.K. (2007). Seasonal incidence of predator Menochilus sexmaculatus Berliner on brinjal and harmful effect of insecticides on the predator. Indian Journal of Agriculture Research, 41(2), 102-106.

[13] Ghosh, S.K., Laskar, N., Basak, S. N., and senapati, S.K. (2004). Seasonal fluctuation of Bemisia tabaci on brinjal and evaluation of pesticides under terai region of West Bengal. Environment and Ecology, 22(4), 758-762.

[14] Ghosh, S.K., Mandal, T., Biswas, S., and Chakraborty, K. (2012). Field evaluation of cultivars and bio-efficacy of insecticides against pest complex of ladysfinger. Journal of applied Zoological Research, 23(2), 121-128.

[15] Ghosh, S.K., Mandal, T., and Chakraborty. K. (2013). Efficacy of chemical insecticides and neem oil against white fly (Bemisia tabaci Genn.) Infesting ladysfinger (Abelmoschus esculentus L.). International Journal of Bio-resource and Stress Management (special). 4(2), 348-351.

[16] Mandol, T., Ghosh, S.K., and Chakraborty, K. (2016). Seasonal incidence of Thrips tabaci infesting Machilus bombycina and their management. International Journal of Science Environment and Technology, 5 (4), 2245-2256. 
[17] Priyadarshini, S., Ghosh, S.K., Nayak, A.K. (2019). Field screening of different chilli cultivars against important sucking pests of chilli in West Bengal. Bulletin of Environment, Pharmacology and Life Sciences. (JEZS), 8(7),134-140.

[18] Subba, B., Pal, S., Mandal, T., and Ghosh, S.K. (2017). Population dynamics of Bemisia tabaci Infesting tomato and their sustainable management using bio-pesticides. International Journal of Entomology and Zoology studies, 5(3), 879-883

[19] Thakoor, P., Ghosh, S.K., Nihal, R., and Ramya Sri, N. (2019). Effect of abiotic factors on seasonal incidence and bio-efficacy of newer insecticides against Aphis gossypii in tomato. International Journal of Entomology and Zoology studies. (JEZS), 7(3),513-516.

[20] Thakoor, P., Ghosh, S.K., and Bala, S.C. (2020). Effect of abiotic factors on seasonal incidence and bio-efficacy of newer insecticides against white fly on tomato. International Journal of Entomology and Zoology studies. (JEZS), 8(3), 267-271. 